A Journal of Culture, English Language, Teaching \& Literature ISSN 1414-3320 (Print), ISSN 2502-4914 (Online)

Vol. 18 No.2; December 2018

Copyright $\odot$ Soegijapranata Catholic University, Indonesia

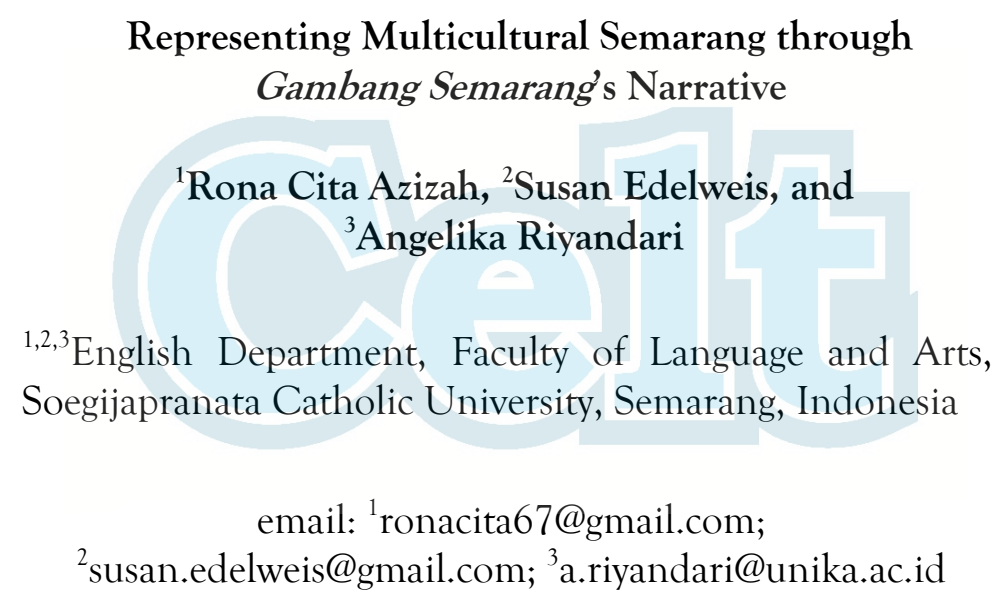

Received: 19-01-2018

Accepted: 24-06-2018

Published: 23-12-2018 


\title{
Representing Multicultural Semarang through Gambang Semarang's Narrative
}

\author{
${ }^{1}$ Rona Cita Azizah, ${ }^{2}$ Susan Edelweis, and ${ }^{3}$ Angelika \\ Riyandari \\ 1'ronacita67@gmail.com; 2susan.edelweis@gmail.com; \\ 3a.riyandari@unika.ac.id \\ ${ }^{1,2,3}$ English Department, Faculty of Language and Arts, \\ Soegijapranata Catholic University, Semarang, Indonesia
}

\begin{abstract}
Dance is usually perceived as a structured movement done by a person or more and accompanied by music and in some cases songs. The attention on physical movement often neglects the narrative which may exist behind a dance. Dances often have stories which frame the sequence of movements done by the dancers. The stories in a dance have elements of literature such as theme, plot, characters, and setting. This paper which is part of an on-going research on Semarang traditional dance discusses the story told through the movements and costume of Gambang Semarang dance. Gambang Semarang is traditional performing arts from Semarang which originally consists of music, vocal, dance, and comedy. Gambang Semarang dance was a small part of Gambang Semarang performance, but it is often performed separately from the complete performance now. The dance is commonly accompanied by Gambang Semarang music which combines Javanese music instruments, gamelan, and Chinese music instruments. In some occasions, songs such as Gambang Semarang and Gado-Gado Semarang are presented along with the music. Gambang Semarang dance itself is often considered as Semarang's identity as the dance tries to embrace the multicultural society of Semarang which are Javanese, Chinese, and Arabs through the dance movements and the costume worn by the dancer. Data were collected through interviews with key informants. The results of the interviews then were analyzed to find out the stories represented by Gambang Semarang. The findings show that dance movements and costumes of Gambang Semarang indeed represent multicultural Semarang.
\end{abstract}


rang through Gambang Semarang's Narrative

Key words: dance, narrative, multicultural society, Gambang Semarang

\begin{abstract}
Abstrak: Tari biasa diartikan sebagai gerakan terstruktur yang dilakukan oleh satu orang atau lebih sambil diiringi oleh musik dan kadang-kadang diiringi oleh nyanyian. Perhatian pada gerakan fisik tari sering mengesampingkan naratif yang mungkin ada dibalik sebuah tarian. Tarian sering memiliki cerita yang membingkai rangkaian gerakan yang dilakukan oleh para penari. Cerita dalam suatu tarian mempunyai unsir-unsur yang ada dalam sastra seperti tema, alur cerita, karakter, dan latar belakang. Artikel ini merupakan bagian dari penelitian yang sedang berjalan tentang tari tradisional Semarang yang meneliti cerita yang disampaikan melalui gerakan dan kostum tari Gambang Semarang. Gambang Semarang adalah pertunjukan tradisional dari Semarang yang menampilkan kombinasi musik, nyanyian, tarian, dan komedi. Tarian Gambang Semarang adalah bagian kecil dari pertunjukan Gambang Semarang, tetapi sering dipertunjukkan secara terpisah. Tarian ini biasanya diiringi oleh musik Gambang Semarang yang menggabungkan instrumen musik Jawa, gamelan, dan instrumen musik Cina. Dalam beberapa pertunjukan, nyanyian seperti Gambang Semarang and Gado-Gado Semarang digunakan sebagai iringan bersama dengan musik Gambang Semarang. Tari Gambang Semarang sendiri sering dianggap sebagai tarian identitas Semarang karena tari ini menggambarkan masyarakat multikultural di Semarang yang terdiri dari suku Jawa, Cina, dan Arab melalui gerakan tarian dan kostum yang digunakan oleh penari. Data dikumpulkan melalui wawancara dengan beberapa informan utama. Hasil wawancara kemudian dianalisa untuk menemukan cerita yang terkandung dalam tarian Gambang Semarang. Hasil penelitian menunjukkan bahwa gerakan tari dan kostum Gambang Semarang menggambarkan masyarakat Semarang yang multikultur.
\end{abstract}

Kata kunci: tari, narratif, budaya multikultural, Gambang Semarang 
256 Celt: A Journal of Culture, English Language Teaching \& Literature, Volume 18, Number 2, December 2018, pp. 254 - 266

\section{INTRODUCTION}

Semarang is a city in the north coast of Java Island and the capital city of Central Java Province, Indonesia which is inhabited by a mix background of people such as Javanese, Chinese, Arabs. The variety of Semarang inhabitants' backgrounds is represented by Gambang Semarang, a traditional performing art which is considered as the identity of Semarang (Puguh, 2000). Gambang Semarang originally consists of music, vocal, dance, and comedy. Only later, Gambang Semarang dance is performed separately. This dance is commonly accompanied by Gambang, Semarang traditional musical instruments, which combine Javanese gamelan, Chinese music instruments like tehyan, kongahyan, sukon, and western music instrument such as trumpet (Puguh, 2000). In many occasions, the dance is accompanied by songs such as Gambang Semarang song and Gado-gado Semarang song.

As an identity of Semarang, information on Gambang Semarang dance is supposedly easy to find, however, it is not the case as information found in sources on Gambang Semarang dance only mentions Gambang Semarang dance as a traditional dance of Semarang and nothing more. There is no satisfying information on what the background is, who the dancers are, what the dance symbolizes, and how it is danced. Inadequate information on Gambang Semarang is probably caused by the history of Gambang Semarang itself. Puguh et al (2000) write that in its early years, Gambang Semarang was popular among particular group of people, then in its development, Gambang Semarang became more popular. The popularity of Gambang Semarang during 1970-1980 was proved by the record of its performance in many events including Night Market (Pasar Malam), Indonesian Independence Day events, religious events like ramadhan and Ied, government offices events, and personal events like wedding party. Post 1980s, the popularity of Gambang Semarang is decreasing.

The decrease was noticed by the government of Semarang Municipality who at that time released a political agenda to revive Gambang Semarang. One of the way to revive Gambang Semarang, according to Puguh et al was by way of collaboration between government institutions and higher educations (universities) to develop new versions of Gambang Semarang. Whether the government policy mentioned above is successful or not is unknown. In the researchers own experiences, Gambang Semarang performance in public becomes less and less frequent. The decreasing popularity of traditional performance is a common phenomenon in Java. Hughes-Freeland (2012) writes, "Performance venues in Indonesia and elsewhere in Asia nowadays 
normally include hotels, heritage shows, arts-and-culture festivals, national and religious holidays, carnivals, and documentation and revival projects." HughesFreeland's opinion shows that traditional arts no longer belong to public as part of their life but mainly as an entertainment for 'tourists.'

The facts above motivate the researchers to conduct a study on Gambang Semarang. It is true that the researchers' academic background is English literature. Yet, the researchers decide to take Gambang Semarang dance as the object of study. Following the definition proposed by McRae (1991), literature should no longer be narrowly defined as merely a study of literary works, which is often narrowed down to the study of texts written by literary writers. Literature with small 'l' argued McRae may include non-canonical texts such as advertisements, comics and cartoons, or songs.

McRae bases his idea on the concept of representational language, a language which needs imagination of the receivers to get a potential meaning. McRae explains that "the representational materials do not necessarily have to be verbal although the responses intended to be spoken or written (1991, p. 9). Dance, therefore can be categorized as representational language. The movement of the dance and the costumes worn by the dancers are believed by the researchers to possess certain meanings which indeed need receivers' imagination to decode. Another reason for conducting this study is that the researchers feel responsible to preserve the record of Gambang Semarang, Semarang local culture with the expectation that the next generation will still be well informed of its existence.

Dance movements have meanings as they help to deliver message from the dancers to the viewers. For example, the movements in Ronggeng dance as explained by Raffles (1817) in his book The History of Java. In Raffles's perception, the movements in ronggeng dance are distorted because, according to Raffles, the dancers bended their hands and arms unnaturally. Raffles described further that the handkerchief carried by the dancer was thrown over the dancer's shoulder and the fan that was on the hand of the dancer was often used to cover half of the dancer's face to imitate the movement of a huntsman. Raffles also mentioned that ronggeng dance often did disgraceful postures and motion which he interpreted as the dancers' effort to attract audience to dance with them and give them money.

Like dance movements, dance costumes also have meanings. Bonds (2008) in her study about Beijing Opera costumes says that Chinese Beijing Opera performers wear rich costumes and props. She explains that during the 
258 Celt: A Journal of Culture, English Language Teaching \& Literature, Volume 18, Number 2, December 2018, pp. 254 - 266

$19^{\text {th }}$ century, the costumes worn by the characters in the opera depend on types of story and gender. Social class and the age of the character also influence type of costumes worn. Bonds gives example of the robes worn by the dancers. Bonds records four types of robes.

The first one is Mang (court robe), the second one is $\mathrm{Pi}$ (formal robe with central opening), the third one is Kao (stage armor for high - ranking general) and the fourth one is Xuezi (informal robe with asymmetric opening). The previous brief explanation gives idea to the viewers on who the actors represent in the performance. The way costumes help the viewers to understand the characters' characteristics and roles in the performance as explained by Bonds is also employed by the researchers to explain Gambang Semarang dance.

\section{METHODOLOGY}

The type of research used in this study is qualitative research. The research consists of collecting data by using form, emerging questions to the informant to generate responses, gathering word or image data and collecting information from the individual (Creswell, 2003)

Data for this study were collected in two ways. The primary data were obtained through interviews with key informants, while the secondary data were acquired from books, journals, and internet sources. John W. Creswell mentions that data collection methods include observations, interviews, and documentation as well as recording (Creswell J. W., 2009). In this study, the researchers used observation, interview, and documentation.

The first method done was observation. Observation was done to collect data about the dance movements and costumes of Gambang Semarang's dancers in their live dance performance. The aim of this method is to see how the dancers move and what the dancers wear as their costumes a real performance. The second method was interview. Interviews were conducted to collect data on the narratives of Gambang Semarang's dance movements and costumes from key informants. During interview, the researchers questioned respondents, in this case the key informants, to get deeper information.

In this study, the researchers interviewed a Gambang Semarang dancer, a dance choreographer and owner of a dance company in Semarang, a Gambang Semarang researcher, and a Gambang Semarang dance teacher. The third method was documentation. Documentation was done to record the data at 
Azizah, R.C., Edelweis, S. \& Riyandari, A., Representing Multicultural Sema-

rang through Gambang Semarang's Narrative

the time of interview by means of voice recorder, still picture camera, and video camera. The purpose of this method is to have more accurate, more trusted, and more reliable data. Then, researchers collected written data from journals, books, or internet sources to support data obtained from observation and interview.

In order to find information on the narrative of Gambang Semarang's dance movements and costumes, the researchers needed to decide reliable key informants. Yet, in this research, finding key informants was a challenged. The initial contact met by the researchers proved unable to supply researchers with the needed information on the narratives of Gambang Semarang's dance movements and costumes from key informants. Fortunately, this contact provided the researchers with potential key informants and a research report written by previous study of Gambang Semarang art performance.

This type of method to find key informants is called snowball sampling method. It is used when the interviewer asks the informants to recommend other person who could contribute or participate in the research (Bienacki \& Waldorf, 1981). At the end, the researchers were able to collect data from a Gambang Semarang dancer, a dance choreographer and owner of a dance company in Semarang, a Gambang Semarang researcher, and a Gambang Semarang dance teacher.

The data collected was analyzed using qualitative method by making interpretations (Creswell J. W., 2009). In this study, the writer made interpretations of results obtained from interviews with the support of theories provided by journals, books and internet sources. Lastly, the writer wrote the report of the result.

\section{FINDINGS AND DISCUSSION}

The findings and discussion of this study will be divided into two, the first one is on dance movements and the second one is on costumes.

\section{A. Gambang Semarang dance movements}

The first part of the findings and discussion is Gambang Semarang dance movements. Based on the interview done, the key informant, who is a Gambang Semarang dancer, revealed that the movements of Gambang Semarang dance consist of two groups of movements: main movements and supportive 
260 Celt: A Journal of Culture, English Language Teaching \& Literature, Volume 18, Number 2, December 2018, pp. 254 - 266

movements. The main movements are Ngondhek, Ngeyek, and Genjot, while the supportive movements are Sikap, Lenggang, Ngadhang, Ngembat, Ngombak, Sorong, Mendhak. For the purpose of this paper, the movements explained will only be the main movements.

Figure 1:

Ngondhek Position

(Edelweis, own photo, 2017)

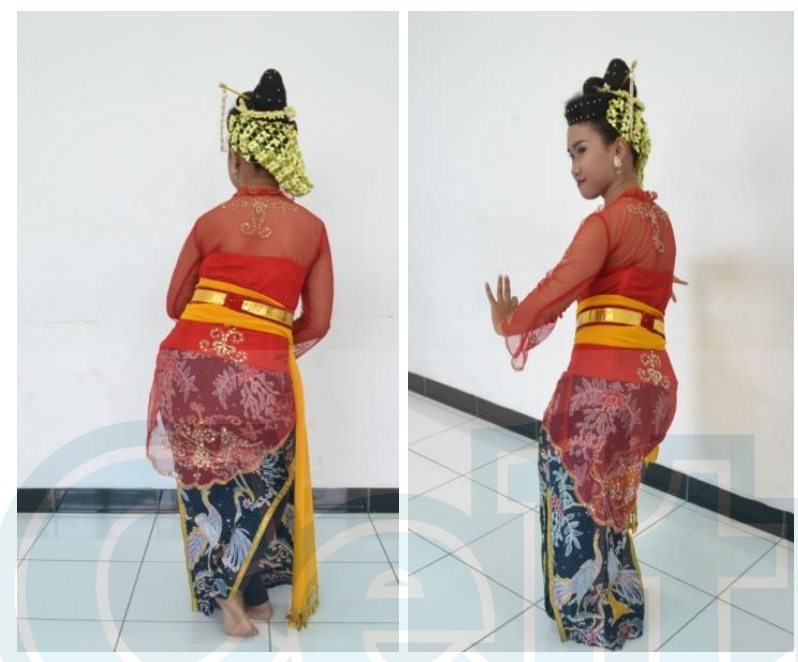

The first main movement is Ngondhek. Ngondhek is a movement of hips resembling number 8 . The dancer said that according to her coach, Ngondhek movement imitates the movement of a catfish, wriggly but subtle. The dancer claimed that hip movements are special feature of Gambang Semarang dance. Ngondhek is not one uniformed movement since it has variation of style. One other variation is by putting both hands on the hips and swinging the hips from left to right and reverse. The second main movement is Ngeyek. Similar to ngondhek, ngeyek is also a hip movement style. The difference is that when ngondhek movement is subtle, ngeyek movement is fractured.

Ngeyek movement is done in two ways, with the dancer standing still in her place or with the dancer making steps to the right and to the left. While the dancer is doing ngeyek, she bends both arms and places her hands in front of her, with the back of her palms facing her. The movements are done repetitively. The third main movement is Genjot. Genjot's movement, stated the dancer, is another hip movement, only this time, the dancer does a tiptoeing movement alternately between her left leg and her right leg.When the movement is done, the right hand palm and the left hand palm are 
Azizah, R.C., Edelweis, S. \& Riyandari, A., Representing Multicultural Sema-

rang through Gambang Semarang's Narrative

positioned to face each other and flipped alternately showing the front and the back of the palms. These main movements are performed at the first part of Gambang Semarang dance and repeated at least 6 times. All movements of Gambang Semarang dance should be done firmly, not delicately. The firm movements, based on the dancer's statement, represent the strong character of Semarang people.

The meaning of the movement is best understood when it is analyzed using the entry point of the songs accompanied Gambang Semarang dance. The first song is Gambang Semarang song in which its first lines of two verses go:

\author{
Empat penari kian kemari \\ jalan berlenggang aduh \\ [four dancers amble here and fro \\ Subtly by moving their hands] \\ Sambil menari jongkok berdiri \\ kaki melintang aduh \\ [(the dancers) dance by squatting and standing \\ One leg crosses other leg]
}

The movements of Gambang Semarang dance are vividly presented in the song. The first verse shows how the dancers move around following the rhythm of the music. The second verse shows the dynamic of the movements in which the dancers shown of doing squatting and standing movements (repeatedly) and of putting one leg across the other leg. Those two verses combine with the explanation of the dancer about the Gambang Semarang dance movements represent the characteristics of Semarang people, which are strong and dynamic. Being strong and dynamic is a typical representation of north coast area people in contract to being gentle and well-measure, a typical representation of inland people.

The same strong and dynamic movements are performed accompanied by other song, Gado-Gado Semarang, which first verse goes:

Semarang yo yu kuta pesisir

Akeh uwong manca kang pada mampir

Ana Koja kok jarene Encik

Dhandanggula dicengkok cara Mandarin 
262 Celt: A Journal of Culture, English Language Teaching \& Literature, Volume 18, Number 2, December 2018, pp. 254 - 266

[Semarang is a coastal area

Where many foreigners come to visit

There are Kojas (Gujarat descendent) who are called Encik (An Indian is usually called Encik).)

Dhandanggula (one of Javanese traditional songs) is sung in Chine style]

This particular song acknowledges the existence of foreigners, Koja (the descendent of people coming from Gujarat), and Chinese. Add up with Javanese people who originally inhabit the area of Semarang, these people form a multicultural society. That Semarang is a harbor city supports the development of its multicultural society. The harbor enables people from places near and far come to Semarang to trade. Some of the visitors then stay permanently in Semarang. These new settlers definitely bring their own habits and customs.

\section{B. Gambang Semarang dance costume}

The second part of the finding and discussion is Gambang Semarang dance costume. The result of the interview with a Gambang Semarang dancer reveals that there is no uniformity in Gambang Semarang dance costume worn by Gambang Semarang dancers. So, basically, the costume worn by dancers from one dancing company or one dancing group can be different from that of other company or group.

The dancing costume is also flexible within a dance group in which one group may modify their costumes for each performance. Since the dancer interviewed for this study is a dancer from GSAC (Gambang Semarang Art Company), then the costume discussed will be costume worn by GSAC dancers. Basically, costume worn by Gambang Semarang dancer comprises two main part, the upper part costume and the below part costume. Based on the interview, the researchers found out that the upper part Gambang Semarang dance costume consists of body wrap (kemben), Kebaya, long scarf (sampur), and belt.

The upper part costume of Gambang Semarang dancer is typically related to costume worn traditionally by most Javanese women. However, the details are different. The first detail is the kemben or the body wrap (see Figure 2). Traditionally kemben or body wrap is made of batik cloth which is actually wrapped around the body. In the costume above, it can be seen that the body wrap has been modified to a ready use body wrap in color matched to the 
Kebaya color. The second detail is the kebaya (see Figure 3). Kebaya worn by Gambang Semarang dancer is not a traditional Javanese kebaya but kebaya encim. Kebaya encim is a modification of Javanese kebaya worn by Tionghoa Peranakan and Indo Belanda (Lukman, Amir, \& Sunarto, 2013, p. 15).” Tionghoa Peranakan was a term used to describe descendent of a mix marriage between Chinese (usually the father) and a Javanese, while Indo Belanda was a term to describe descendent of a mix marriage between Dutch (usually the father) and Javanese.

Figure 2: Kemben (Azizah

own photo, 2016)

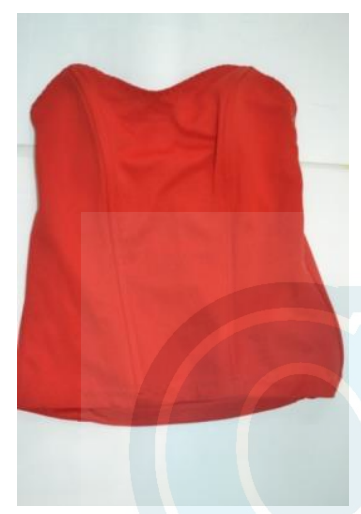

Figure 3: Kebaya (Azizah own photo, 2016)

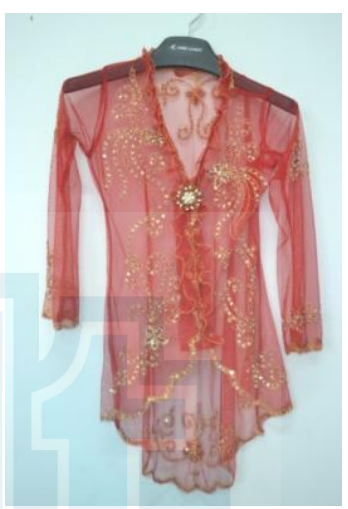

Kebaya encim, as explained by Lukman et al. (2013), features more luxurious fabric than kebaya fabric worn by Javanese women. Lukman et al. (2013) explains that earlier, Tionghoa Peranakan worn the same type of kebaya as Indo Belanda which was a white expensive fabric kebaya with lace (p. 15). Then, the Tionghoa Peranakan modified their kebaya into kebaya kerancang where the lace was substituted with perforated fabric embroidered to look like lace. Later, the Tionghoa Perananakan substituted the white fabric with a more colorful thin fabric embroidered with China's ornament design (p. 15).

Figure 3 shows a kebaya encim with thin material and bright red color. This Kebaya is also embroidered with ornaments. Unfortunately, the ornament in kebaya encim worn by GSAC dancer cannot be clearly defined. In addition, to make the kebaya encim look more luxurious, it is decorated with beads, golden beads.

The third part of the upper part costumes, which is a long scarf (sampur) is a typical costume worn by Javanese women with the modification of beads in the two end parts of the long scarf for the dancers (see Figure 4). The last part 
264 Celt: A Journal of Culture, English Language Teaching \& Literature, Volume 18, Number 2, December 2018, pp. 254 - 266

of upper part costumes is the belt (see Figure 5). According to the key informants, the head of the belt (timang) shows European influence on the costumes.

Figure 4: Sampur (Azizah

own photo, 2016)

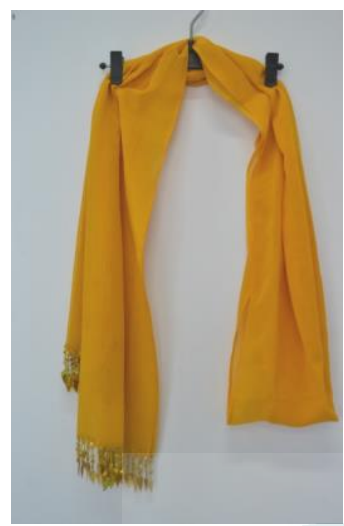

Figure 5: Belt (Azizah

own photo, 2016)

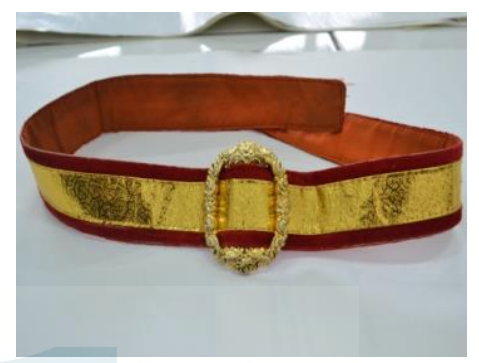

In short, the upper part costumes of Gambang Semarang depict multicultural Semarang which is influenced by Javanese, Chinese, and European people.

The below part costume of a Gambang Semarang dancer is a long cloth (jarik). From the interview, the researchers found that GSAC dancers wear skirt with special batik with Chinese pattern (see Figure 6).

Figure 6:

Jarik (long skirt)

(Azizah own photo, 2016)

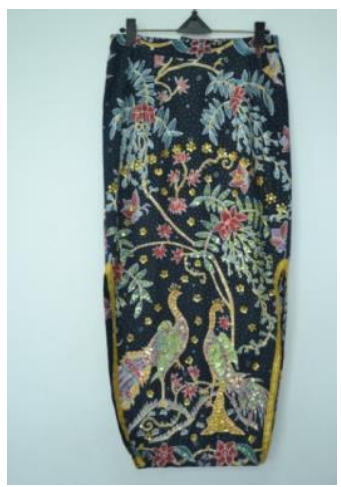

Looking at the color and the pattern of the long cloth worn by Gambang Semarang dancer, the dancer obviously wears pesisiran (coastal area) batik. The 
Azizah, R.C., Edelweis, S. \& Riyandari, A., Representing Multicultural Sema-

rang through Gambang Semarang's Narrative

bright color batik and ornaments portraying animals or plants are typical of pesisiran batik. Pesisiran batik is said to represent Chinese culture in terms of color and to represent coastal area culture in terms of the plant pattern which is usually algae pattern (ganggeng). The explanation about the long cloth worn by Gambang Semarang dancer shows the mix of at least Javanese culture and Chinese culture.

\section{CONCLUSION}

The discussion on the findings and discussion section above definitely shows that Gambang Semarang dance contains narratives which represent multicultural society of Semarang. The dance movements represent strong and dynamic characteristics of coastal area people. The song accompanied Gambang Semarang dance clearly describes multicultural backgrounds of people living in Semarang. They are Javanese, Kojan, and Chinese. The song also mentions that Semarang is visited by foreigners who stay in a short term to trade. Furthermore, Gambang Semarang dance costumes both upper and below part obviously represent mix of cultures of those living in Semarang in terms of costume design, costume color, and costume patterns. The cultures represented in the costume are Javanese, Chinese and European.

\section{REFERENCES}

Bienacki, P., \& Waldorf, D. (1981). Snowball Sampling. Sociological Methods and Research, 10(2), 141-163.

Bonds, A. B. (2008). Beijing Opera Costumes: The Visual Communication of Characters and Culture. Beijing: University of Hawai'i Press.

Creswell, J. W. (2003). Research Design Qualitative, Quantitative, and Mixed Methods Approaches. Lincoln: SAGE Publications.

Creswell, J. W. (2009). Research Design: Qualitative, Quantitative, and Mixed Methods Approaches. London: SAGE Publications, Inc.

Hughes-Freeland, F. (2012). Movement on the Move: Performance and Dance Tourism in Southeast Asia. In H. N. Kringelbach, \& J. Skinner (Eds.), Dancing Cultures: Globalization, Tourism and Identity in the Anthropology of Dance (pp. 100-120). New York, Oxford: Berghahn. 
266 Celt: A Journal of Culture, English Language Teaching \& Literature, Volume 18, Number 2, December 2018, pp. 254 - 266

Lukman, C. C., Amir, P. Y., \& Sunarto, P. (2013). Kebaya Encim as the Pehnomenon of Mimicry in East Indies Dutch Colonial Culture. Arts and Design Studies, 13, 15-22.

McRae, J. (1991). Literature with a Small 'l'. New York, London, Toronto, Sydney, London, Singapore: Prentice Hall.

Puguh, D. R. (2000). Penataan Kesenian Gambang Semarang Sebagai Identitas Budaya Semarang [The Arrangement of Semarang Gambang Art as Semarang Cultural Identity]. Semarang: Universitas Diponegoro Semarang - Dikti Indonesia.

Raffles, T. S. (1817). The History of Java. Yogyakarta: Penerbit Narasi. 